УДК 636.8.09:615.874.2:613.25, DOI 10.31210/visnyk2018.04.22

(C) 2018

Локес-Крупка Т. П., кандидат ветеринарних наук

Полтавська державна аграрна академія

\title{
КЛІНІЧНА ЕФЕКТИВНІСТЬ ДІСТОТЕРАПІЇ У ПРОФІЛАКТИЦІ ОЖИРІННЯ У СВІЙСЬКОГО КОТА
}

\section{Рецензент - кандидат ветеринарних наук Н. С. Щербакова}

\begin{abstract}
Ожиріння і надмірна маса тіла є одним із найбільи частих патологічних станів у дрібних свійських тварин. Ототожнення домашніх тварин із членами сім'ї і перенесення на них власних харчових звичок відіграє значну роль у розвитку ожиріння.

Метаболізм котів, як хижаків, пристосований до засвоєння корму, багатого на білок і вуглеводи. Якщз тварина отримує в раціоні надлишок вуглеводів або крохмалю, то вони не використовуються як джерело енергії $і$ перетворюються на жири. Незбалансований натуральний тип годівлі свійських котів часто призводить до появи надлишкової маси тіла, оскільки власникам важко вираховувати кількість калорій у кожній пориї̈ корму.
\end{abstract}

Ключові слова: кіт, ожиріння, дієтотерапія, рач̧iон.

Постановка проблеми. Ожиріння (лат. Obesitas - «гладкий», «товстий», «пухкий») - це багатофакторне і поліетіологічне захворювання, що супроводжується накопиченням надлишкової кількості жирової тканини в організмі [6]. Під ожирінням розуміють перевищення норми маси тіла більш ніж на $20 \%$ від фізіологічної норми. У нашій країні серед свійських котів ожиріння реєструють більш ніж у 30-40 \%, серед собак у понад 20-30\% тварин.

Основною причиною аліментарного ожиріння $\epsilon$ низька фізична активність, або так звана «гіподинамія тварин». В умовах утримання у квартиpi, рідкого і нетривалого вигулу дрібні свійські тварини недостатньо витрачають отриману 3 кормом енергію, що призводить до надмірного депонування енергетичних запасів в організмі [7].

Ожиріння - чинник, що скорочує тривалість життя домашніх улюбленців. Смертність від ожиріння у тварин становить приблизно $10 \%$ [4]. Надлишкова маса тіла призводить до погіршення здоров'я, впливаючи на роботу і функції всього організму. Серцева, ниркова, легенева недостатності, гіпертонія, гепатоліпідоз, діабет, дисплазія, артрит - лише деякі захворювання, викликані ожирінням. Крім цього реєструються ускладнення під час пологів, зниження ефективності імунної системи, підвищення ризику виникнення злоякісних новоутворень $[5,14]$.

Аналіз останніх досліджень і публікацій, у яких започатковано розв'язання проблеми. Надмірна та незбалансована годівля - один із найважливіших чинників виникнення аліментарного ожиріння. Під час складання раціону потрібно враховувати вік, активність, фізіологічний стан, умови проживання та ступінь вгодованості тварин $[9,10,12,13]$.

Нині визначена як породна, так і статева схильність тварин до ожиріння. Так, у собак частіше страждають самки, у котів - самці. Серед короткошерстих котів європейського типу в більшій мірі схильні до ожиріння метиси, оскільки в чистопородних тварин краще забезпечується генетичний контроль [14]. У дорослих котів віком від 5 до 10 років знижується рівень фізичної активності, що $є$ першопричиною аліментарного ожиріння. Також висока імовірність розвитку патології в стерилізованих тварин, оскільки в них підвищується апетит, знижується рухова активність і виникають гормональні порушення [12]. Але через те, що поведінка котів, які утримуються в будинках, мало змінюється, то таке зниження витрат енергії найчастіше буває зумовлено зменшенням основного рівня обміну речовин, що стимулює надмірне депонування жиру [2].

Розвиток жирової інфільтрації внутрішніх органів, особливо печінки, гепатоліпідоз - одне 3 найбільш небезпечних ускладнень ожиріння. Це спричиняється тим, що значна кількість жирних кислот швидко вивільняється 3 периферичних жирових депо [1, 15].

Внаслідок видової інсулінорезистентності в котів особливою небезпекою за ожиріння є можливий розвиток цукрового діабету другого типу. Це захворювання безпосередньо пов'язане з акумуляцією жиру і порушенням обміну глюкози в організмі [11].

Метою роботи $\epsilon$ визначення клінічної ефективності дієтотерапії за ожиріння у свійського кота.

Матеріали і методи досліджень. Дослідження проводились на базі клініки ветеринарної медицини кафедри терапії імені професора П. І. Локеса Полтавської державної аграрної академії. 


\section{ВЕТЕРИНАРНА МЕДИЦИНА}

Об'єктом досліджень був свійський кіт породи шотландська висловуха (самка Лола віком сім років) із діагнозом ожиріння. Для встановлення діагнозу проводили клінічні, морфометричні, інструментальні дослідження і лабораторні дослідження крові.

Результати досліджень. До клініки ветеринарної медицини звернулись господарі тварини зі скаргами на задишку, періодичну кульгавість i порушення акту дефекації у кішки. 3 даних анамнезу стало відомо, що такий стан у тварини спостерігався більше місяця з наростаючою прогресією. Зі слів господаря стало відомо, що кішка практично не рухається по квартирі, часто спить, рідко грає. Тварина утримується на змішаному раціоні, що включає в себе каші, м'ясо, хлібобулочні та ковбасні вироби, а також в мисці постійно знаходиться сухий корм промислового виробництва (економ-клас). Лікування самостійно не проводили.

Під час проведення клінічних досліджень відмічали порушення метаболізму, а саме ожиріння (бальна оцінка вгодованості 5/9 балів) [5]. На момент досліджень вага тварини становила 7,3 кг, загальний стан - пригнічений (рис. 1). Обтяжливим фактором є генетичні особливості Лоли, оскільки порода схильна до ожиріння - як аліментарного, так і ендокринного [8]. Періодичні закрепи і проноси можуть бути викликані як неправильним харчуванням, так і внаслідок патології ліпідного обміну.

Виникнення кульгавості, ймовірно, обумовлено збільшенням маси тіла тварини та значним тиском на суглоби. Також викидання лап під час ходьби обумовлено великим скупченням жирових відкладень в області нижньої частини живота, що анатомічно заважають фізіологічним рухам кішки.

Ультрасонографічне дослідження дозволило виявити значне скупчення вісцерального жиру, що значно погіршувало візуалізацію внутрішніх органів. Структура печінки і нирок була характерна для виду і віку тварини, без патологічних змін.

Першим заходом для поліпшення стану тварини було рекомендовано провести корекцію раціону i організувати моціон. Як дієтотерапію використовували готовий корм «Royal Canin Satiety» протягом трьох місяців, дозування - згідно з рекомендаціями виробника. Також рекомендовано використання пробіотиків. Для поліпшення стану суглобів призначено препарати хондроїтину з глюкозаміном протягом місяця. Як моціон господарям рекомендовані активні ігри з кішкою.

Вторинний прийом був проведений на 10-й день терапії. За такий короткий проміжок часу маса тіла тварини не змінилася. Позитивною зміною було зменшення больових відчуттів у колінних і скакальних суглобах. Під час наступних візитів (через місяць, два, три) було зареєстровано зниження маси тіла, зменшення жирових відкладень, поліпшення якості рухів кішки. Через три місяці дієтотерапії вага Лоли становила 5,2 кг (рис. 2), вона стала більш грайливою, задишка не реєструвалася, акт дефекації нормалізувався.

У подальшому рекомендований перехід на дієту згідно з породою і віком тварини.

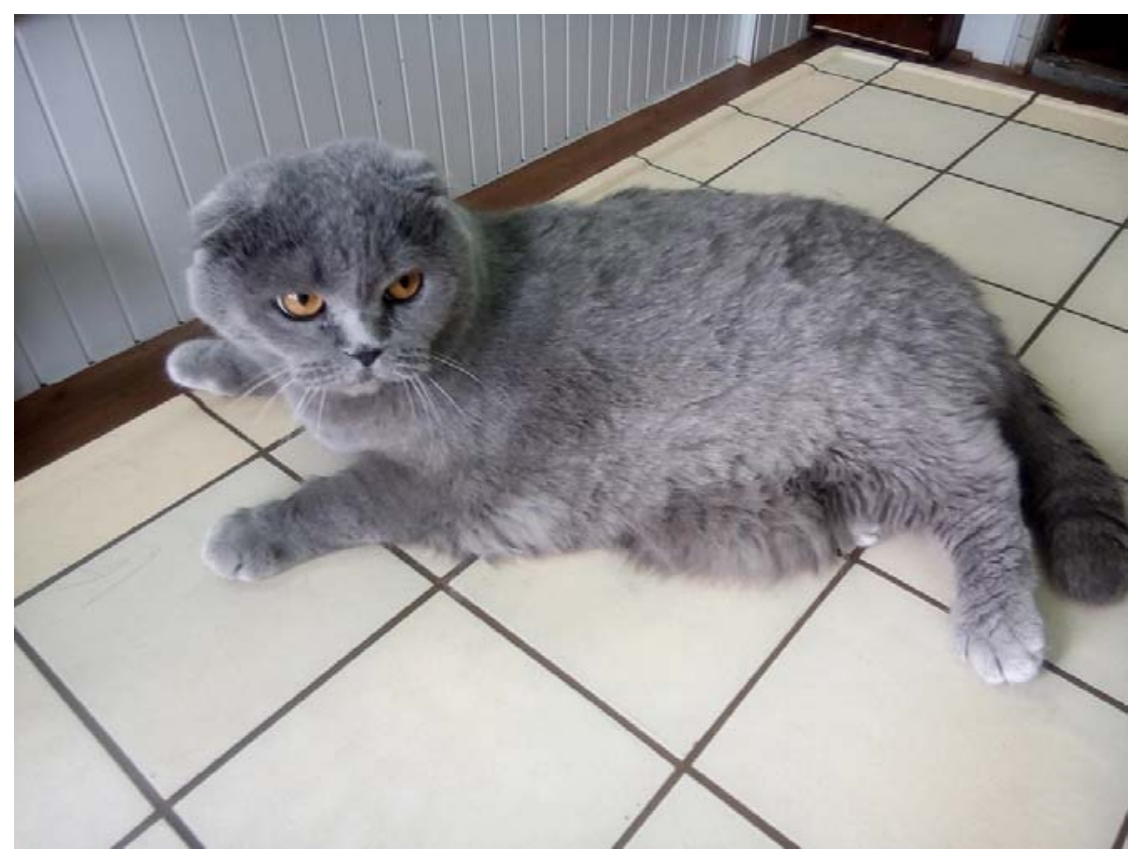

Рис. 1. Загальний вигляд Лоли на початку дослідження 
ВЕТЕРИНАРНА МЕДИЦИНА

\section{1. Біохімічні показники сироватки крові свійського кота за ожиріння}

\begin{tabular}{|c|c|c|c|}
\hline № 3/п & Показник & Лола & Норма (Lim) \\
\hline 1 & Загальний білок, г/л & 82,1 & $55-79$ \\
\hline 2 & Глобуліни, г/л & 47,2 & $32-45$ \\
\hline 3 & Глюкоза, ммоль/л & 6,0 & $3,3-5,5$ \\
\hline 4 & АлАТ, МО/л & 58,3 & $25,0-59,0$ \\
\hline 5 & АСАТ, МО/л & 42,7 & $19,0-44,0$ \\
\hline 6 & Креатинін, мкмоль/л & 125,2 & $70-140$ \\
\hline 7 & ЛФ, МО/л & 92,4 & $15,0-87,0$ \\
\hline 8 & ГГТП, МО/л & 11,9 & $3-9$ \\
\hline 9 & Тригліцероли, ммоль/л & 1,45 & $0,22-0,96$ \\
\hline 10 & Загальний холестерол, ммоль/л & 6,42 & $1,44-4,61$ \\
\hline 11 & ЛПНЩ, ммоль/л & 4,21 & $0,10-1,26$ \\
\hline 12 & ЛПВЩ, ммоль/л & 1,62 & $1,22-3,11$ \\
\hline
\end{tabular}

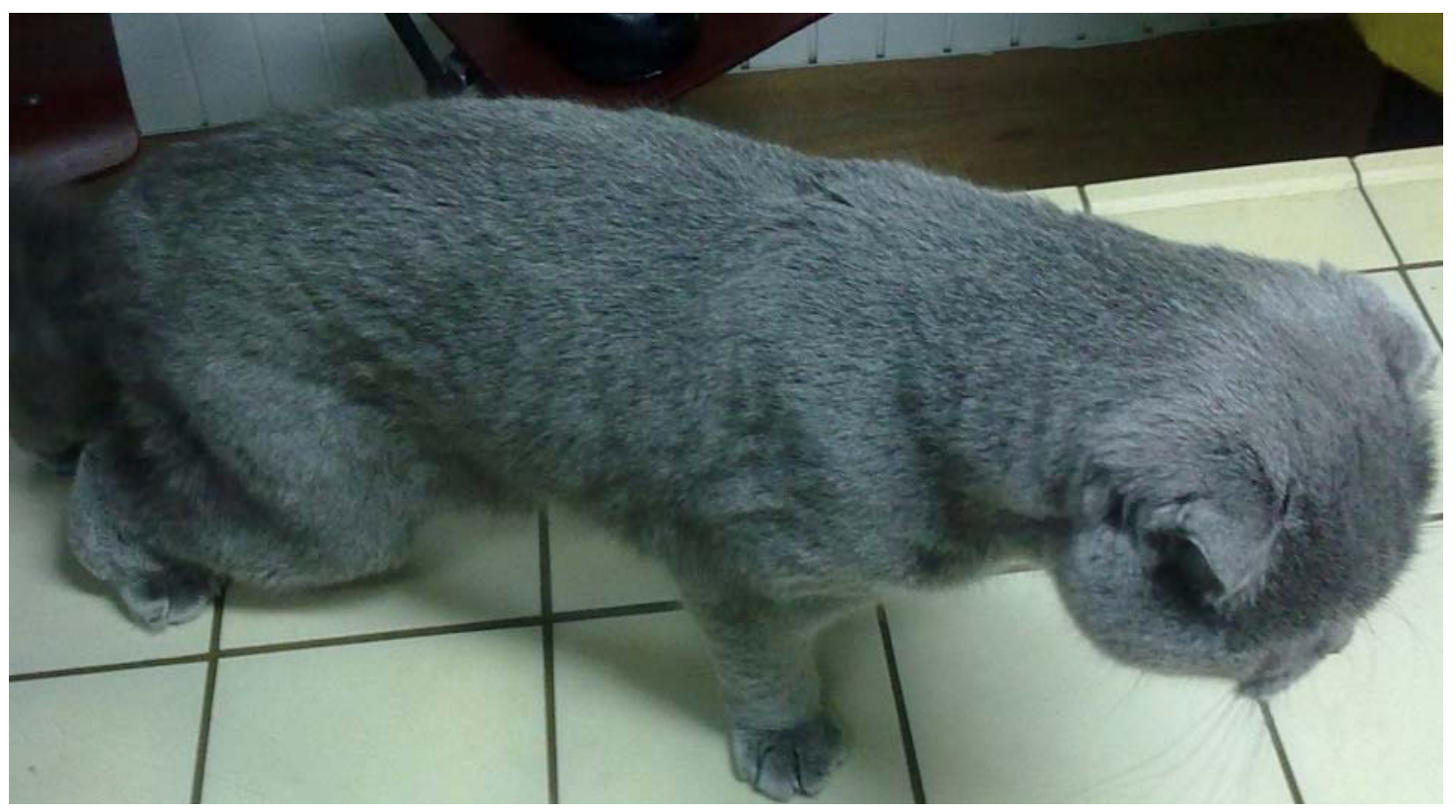

Рис. 2. Загальний вигляд Лоли після курсу лікування

Висновок. Отже, базуючись на результатах клінічних та лабораторних досліджень, можна стверджувати, що для забезпечення нормального метаболізму і усунення ризику розвитку ожиріння у свійських котів необхідно:

\section{БІБЛІОГРАФІЯ}

1. Гарбузенко Д. В. Механизмы компенсации структуры и функции печени при ее повреждении и их практическое значение / Д. В. Гарбузенко. // Рос. журнал гастроэнтерол., гепатол., колопроктологии. - 2008. - Т. 18, № 6. - С. 14-22

2. Герман А. Клинические осложнения ожирения у мелких домашних животных. - WALTHAM
- прогулянки,

- збалансований раціон,

- відсутність ласощів і подачок зі столу,

- чітке дотримання кратності годування i кількості готового корму.

Focus, T. 16, 2006, №1. - C. 21-26.

3. Гуляева Д.А. Ожирение и сахарный диабет у собак и кошек: этиология и диетотерапия / Д.А. Гуляева // Ж-л "Ветеринарная практика" 2006, №4 (35). - С. 30-32.

4. Дегасс Ж., Гети С., Шуберт А., Мюллер Ж. / Ожирение - основной фактор риска сахарного 


\section{ВЕТЕРИНАРНА МЕДИЦИНА}

диабета у кошек // Ж-л «Ветеринар». - 2002 №2. - C. $38-40$

5. Диез М. Бальная оценка упитанности кошек и собак / М. Диез // Focus Waltham. - 2006. Т. 16, №1. - С. 39-40.

6. Ирака Д. Подход к ожирению собак, учитывающий этологические особенности животных этого вида // Д. Ирака, С. Хиз, К. Халсберг // WALTHAM Focus (Спец. выпуск). - 2006. C. 11-15.

7. Лафламм Д. П. Хищники и углеводы / Д. П. Лафламм // Отчет о научно-исследовательской работе Purina Pet Institute. - 2005. - Вып. 3, C. 3-7.

8. Московкина Н. Н., Сотская М. Н. Генетика и наследственные болезни собак и кошек. - М.: ООО "АКВАРИУМ ЛТД", 2000. - 448 с.

9. Симпсон Дж. В. Клиническое питание собак и кошек : Руководство для ветеринарного врача / Дж. В. Симпсон, Р. С. Андерсон, П. Дж. Маркуелл ; пер. с англ. Е. Махиянова. - М. : Аквариум ЛТД, 2001. $-256 \mathrm{c}$.

10. Association of American Feed Control

\section{ANNOTATION}

Lokes-Krupka T. P. Clinical effectiveness of diet therapy in preventing domestic cat obesity.

The purpose of the work is to determine the clinical effectiveness of diet therapy in case of domestic cat obesity. The cat's owners addressed the veterinary clinic with complaints of labored breathing, periodic claudication, and defecatory disorders. Judging by the owner's words, the cat practically did not move in the apartment, often slept, and rarely played. The animal was kept in a mixed diet.

The weight of the animal was $7.3 \mathrm{~kg}$, the general condition was depressed. The percentage of fat deposits was over $35 \%$, which confirmed obesity.

Changes in the morphological analysis of blood were insignificant and not specific for differential diagnosis. Characteristic serological changes were: hyperproteinemia; hyperlipidemia; cholestasis syndrome. Liver and renal markers were within the physiological norm.

The first step to improve the animal's condition
Officials (AAFCO). AAFCO dogs and cats nutrient profiles. Official publication. - 2003. - P. 125-140.

11. Castera L. Steatosis, insulin resistance and fibrosis progression in chronic hepatitis C / L. Castera // Minerva Gastroenterol. Dietol. - 2006. - Vol. 52 (2). - P. 125-134.

12. German A. $J$. Weight management in obese pets: the tailoring concept and how it can improve results // A. J. German / Acta Vet Scand. - 2016. Vol. 20; 58 (Suppl 1) - P. 57.

13. Halton T. L. The effects of high protein diets on thermogenesis, satiety and weight loss: a critical review / T. L. Halton, F. B. Hu // J. Am. Coll. Nutr. - 2004. - Vol. 23, № 5. - P. 373-385.

14. Jose J. Ceron Obesity-related metabolic dysfunction in dogs: a comparison with human metabolic syndrome Asta Tvarijonaviciute / Jose J. Ceron, Shelley L. Holden, Daniel J. Cuthbertson [et al.] // BMC Veterinary Research - 2012, Vol. 8 - P. 147

15. Kearns S. Infectious hepatopathies in dogs and cats / S. Kearns. // Top Companion Anim. Med. - 2009. - Vol. 24 (4). - P. 189-198.

was the recommendation to conduct diet correction and organize exercises. As diet therapy, "Royal Canin Satiety" was used for three months. It was also recommended to use probiotics and chondroitin with glucosamine for one month. For movement we recommended active games with the cat.

During the subsequent visits, the decrease of body weight, fat deposits, and improvement of the quality of the cat's movements were observed. After three months of diet therapy, Lolla's weight was $5.2 \mathrm{~kg}$, she became more playful, labored breathing was not recorded, the act of defecation normalized.

Consequently, in order to ensure normal metabolism and eliminate the risk of developing obesity in domestic cats, the following measures are necessary: walks, balanced diet, no delicacies and scraps of food from the table, strict compliance with the frequency of feeding and the amount of finished feed.

Key words: cat, obesity, diet therapy, diet. 